Economics Development Analysis Journal

\title{
Faktor-Faktor yang Mempengaruhi Ekspor Karet Indonesia ke Malaysia Tahun 1983-2013
}

\author{
Aini Kusrini $^{1 \bowtie}$, Arini Novandalina ${ }^{2}$ \\ ${ }^{1}$ Jurusan Ekonomi Pembangunan, Fakultas Ekonomi, Universitas Negeri Semarang \\ ${ }^{2}$ STIE Semarang, Jawa Tengah
}

\section{Info Artikel}

Sejarah Artikel:

Diterima September

2016

Disetujui Oktober 2016

Dipublikasikan

November 2016

\section{Keywords:}

Ordinary Least Square

(OLS), Production, Rubber

Export, Rubber Plantation

Area, USD Rate.

\begin{abstract}
Abstrak
Penelitian ini bertujuan untuk mendeskripsikan Faktor-faktor yang mempengaruhi ekspor karet Indonesia ke Malaysia. Data yang digunakan dalam penelitian ini adalah data sekunder. Dimana data yang diperoleh diwujudkan dalam bentuk angka dan analisis menggunakan metode statistika dan ekonometrika. Penelitian ini menggunakan data runtut waktu (time series). Variabel dalam penelitian ini adalah luas areal lahan, produksi, dan kurs rupiah terhadap ekspor karet Indonesia ke Negara Malaysia.Data di analisis dengan metode kuantitatif. Metode analisis yang digunakan Ordinary Least Square (OLS) dengan menggunakan alat bantu sofware Eviews. Berdasarkan hasil yang diperoleh bahwa luas areal lahan,Produksi,Kurs pada analisis regresi liniear berganda berpengaruh Signifikan terhadap ekspor karet Indonesia ke Malaysia. Luas lahan berpengaruh terhadap ekspor sebesar 2.050, produksi berpengaruh terhadap ekspor sebesar 0.000368, Kurs berpengaruh terhadap ekspor sebesar 0.090. Hasil penelitian dapat diberi saran yaitu Sebaiknya pemerintah dan petani karet bekerjasama meminimalisir pengalihan lahan karet, Pemberian subsidi bibit karet kepada petani karet dan Sebaiknya para eksportir mempelajari strategi dagang internasional sehingga selalu dalam posisi tawar yang baik dalam kondisi apapun.
\end{abstract}

Alamat korespondensi: ISSN 2252-6765

Ruang Jurnal,Gedung L FE UNNES Sekaran Gunungpati

Semarang 50229, Indonesia

E-mail: Aini.kusrini@yahoo.com 


\section{PENDAHULUAN}

Perdagangan luar negeri merupakan salah satu aspek penting dalam perekonomian suatu negara. Dalam situasi globalisasi tidak ada satu negara pun yang tidak melakukan hubungan dagang dengan pihak luar, mengingat bahwa setiap negara tidak dapat memenuhi kebutuhannya sendiri secara efektif tanpa bantuan negara lainnya. Perdagangan luar negeri memberikan harapan bagi negara untuk bisa menutupi kekurangan tabungan domestik yang diperlukan bagi pembentukan modal dalam rangka meningkatkan produktivitas perekonomian. Masing-masing memiliki ketergantungan dengan negara lainnya, karena untuk memenuhi kebutuhannya tidaklah cukup dengan mengandalkan sumber daya dari dalam negeri saja. Keuntungan yang dapat dilihat dari nilai ekspor negara. Jika nilai ekspor yang lebih tinggi dibandingkan nilai impor menunjukkan majunya perekonomian suatu negara dari segi kegiatan perdagangan internasional.

Peningkatan ekspor baik jumlah maupun jenis barang atau jasa selalu diupayakan dengan berbagai strategi diantaranya adalah pengembangan ekspor, terutama ekspor nonmigas, baik barang maupun jasa. Tujuan dari program pengembangan ekspor ini adalah mendukung upaya peningkatan daya saing global produk Indonesia serta meningkatkan peranan ekspor dalam memacu pertumbuhan ekonomi

Indonesia salah satu negara pemasok ekspor migas dan nonmigas di pasar dunia. Dari data statistik yang dikeluarkan oleh Biro Pusat Statistik (BPS), hampir 5.000 macam produk dari Indonesia masuk ke pasar negara-negara tersebut (Kementerian Perdagangan, 2015).

Indonesia merupakan produsen penghasil karet alam terbesar ke dua di dunia dengan produksi 2,5 juta ton setelah negara Thailand. Namun luas areal perkebunan karet alam Indonesia yang terbesar di dunia dengan 3,43 juta hektar atau sekitar 1,5 kali luas kebun karet Thailand (GAPKINDO, 2009). Jumlah ini masih bisa ditingkatkan lagi dengan memberdayakan lahan-lahan pertanian milik petani serta lahan kosong/tidak produktif yang sesuai untuk perkebunan karet.
Produksi karet terbesar di dunia Indonesia masih belum bisa mengolah hasil karet, sehingga Indonesia harus melakukan hal itu di karenakan Indonesia sangat minim teknologi sehingga Indonesia melakukan ekspor karet dalam bentuk mentah. Sebenarnya, selain dapat dimanfaatkan getahnya, pohon karet juga dapat dimanfaatkan kayunya. Sebuah studi kasus yang dilakukan di Kamboja menggambarkan bahwa perkebunan karet selain dimanfaatkan getahnya, juga dapat dimanfaatkan kayunya dalam industri sebagai nilai tambah dari karet tersebut (Shigematsu, 2013).

Karet mentah (natural rubber) maupun produk olahan karet merupakan komoditi yang diperdagangkan secara internasional. Indonesia termasuk negara pengekspor penting dalam perdagangan karet, yang menunjukkan perkembangan yanng berarti setiap tahunnya. Untuk pengembangan dan peningkatan ekspor karet, pemerintah telah mengeluarkan serangkaian kebijakan produksi dan perdagangan produk olahan karet. Selain itu, pemerintah juga harus memberikan perhatian dan perlindungan pada perkebunan karet agar tidak terjadi kerusakan seperti yang terjadi di Benin. Dalam penelitian yang dilakukan di benin menunjukkan perkebunan karet menunjukkan penurunan kinerja karena pemerintah setempat tidak mampu melindungi hutan benin karena eksploitasi yang berlebihan (Fenske, 2013).

Menurut Boediono (2001:10), perdagangan di artikan sebagai proses tukar menukar yang didasarkan atas kehendak sukarela dari masing-masing pihak. Pertukaran timbul karena kedua pihalk melihat adanya keuntungan/manfaat tambahan yang bisa di perolah dari pertukaran tersebut. Manfaat ini disebut manfaat dari perdagangan atau gains from trade. Keuntungan yang timbul dari perdagngan tersebut karena adanya perbedaan selera antara konsumen dan perbedaan dalam jumlah barang.

Permintaan akan suatu barang dipengaruhi oleh banyak faktor-faktor tersebut antara lain harga barang itu sendiri,harga barang lain yang mempunyai hubungan (Subtitusi 
komplementer),pendapatan,selera,dan sebagainya. Hubungan antara jumlah suatu barang yang diminta (sebagai variabel dependen) dengan seluruh faktor yang mempengaruhinya variabel independen), secara matematis dapat dinyatakan sebagai berikut:

$\mathrm{Q}_{\mathrm{d}}=\mathrm{f}\left(\mathrm{P}_{\mathrm{X}, \mathrm{P}} \mathrm{P}_{\mathrm{z}} \mathrm{S}, \mathrm{Y}, ..\right)$

$\mathrm{Q}_{\mathrm{d}}=$ Jumlah barang yang diminta

$\mathrm{P}_{\mathrm{X}}=$ Harga barang $\mathrm{X}$

$\mathrm{P}_{\mathrm{y}}=$ Harga baranag lain

$\mathrm{P}_{\mathrm{z}}=$ Harga barang lain

$\mathrm{S}=$ Selera

$\mathrm{Y}=$ Pendapatan

Hukum permintaan yang menyatrakan apabila harga suatu barang naik dan faktorfaktor lain dianggap tidak berubah (Cateris paribus) maka pembeli cenderung membeli lebih sedikit barang tersebut. Sebaliknya apabila harga suatu barang turun maka pembeli cenderung membeli barang tersebut dalam jumlah yang lebih banyak. (Mankiw,2001:87)

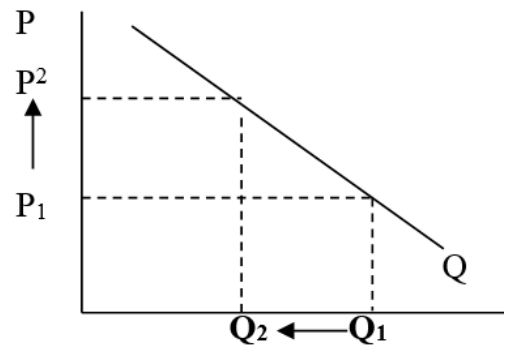

Gambar Kurva Permintaan

Kurva permintaan bergeser ke kiri ataupun ke dkanan.Pergeseran kurva permintaan ke kana terjadi karena dengan sejumlah barang yang sama konsumen bersedia membayar dengan harga lebih tinggi, yaitu dari $\mathrm{P}_{1}$ ke $\mathrm{P}_{2}$ atau dengan harga yang sama konsumen bersedia membeli lebihbanyak,yaitu dari $\mathrm{Q}_{0}$ ke $\mathrm{Q}_{1}$. sedangkan yang menyebabkan pergesran kurva permintaan ke kiri adalah ketika pendapatan meningkat sementara faktor-faktor lain tidak berubah (konstan), maka permintaan untuk suatu komoditas akan meningkat. Selain pendapatan,harga barang lain,selera dan sebagainya juga dapat bergeser kurva permintaan ke kanan dan ke kiri (Pindyck,2007:27).

Harga semua barang selalu dipandang sebagai faktor yang sangat penting dalam memanfaatkan penawaran barang tersebut. Teori penawaran memiliki hubungan di antara tingkat harga dengan jumlah barang yang ditawarkan (Sukirno, 2000:45)

Permintaan akan suatu barang dalam suatu aktivitas ekonomi belum tentu merupakan syarat untuk mewujudkan transaksi dalam pasar. Permintaan akan dapat dipenuhi apabila para penjual/ perusahaan dapat menyediakan barang yang diminta tersebut. Ada beberapa faktor yang mempengaruhi tingkah laku penjual/ perusahaan dalam menawarkan barang-barang yang diperlukan tersebut, salah satunya adalah harga. Harga suatu barang atau jasa selalu dipandang sebagai faktor yang sangat penting dalam menentukan penawaran barang. Oleh karena itu teori penawaran memilki hubungan di antara tingkat harga dengan jumlah barang yang ditawarkan (Sukirno, 2000:45).

Hukum penawaran pada dasarnya mengatakan bahwa: "Semakin tinggi harga suatu barang, semakin banyak jumlah barangtersebut akan ditawarkan oleh para penjual. Sebaliknya, makin rendahharga suatu barang, semakin sedikit jumlah barang tersebut yang ditawarkan.

Berdasarkan pada latar belakang masalah diatas maka penulis tertarik untuk mengetahui seberapa besar pengaruh luas lahan, produksi, dan kurs rupiah terhadap ekspor karet Indonesia ke Malaysia.

\section{METODE PENELITIAN}

Jenis penelitian yang digunakan dalam penelitian ini adalah penelitian kuatitatif. Pada penelitian ini, jenis data yang digunakan adalah data sekunder, sedangkan menurut waktu pengumpulannya, jenis data dalam penelitian ini adalah data (time series) kurun waktu 1983 2013. Sumber data diperoleh dari Badan Pusat Statistik (BPS) Provinsi Jawa Tengah dan Gapkindo.Teknik analisis data yang digunakan adalah deskriptif kuantitatif dan analisis statistik. 
Analisis statistik meliputi regresilinier berganda, uji asumsi klasik (uji normalitas, uji multikolinearitas, uji heteroskedasitas), uji hipotesis (uji F dan uji t), koefisien determinasi $\left(\mathrm{R}^{2}\right)$.

\section{Metode analisis Data}

$Y=a+\beta_{1} X_{1}+\beta_{2} X_{2}+\beta_{3} X_{3}+e$

Dimana :

Y: Variabel ekspor karet

a : Konstanta

$\mathrm{X}_{1}$ : Luas lahan
$\mathrm{X}_{2}$ : Produksi karet

$\mathrm{X}_{3}:$ Kurs

e : Disturbance error

\section{HASIL DAN PEMBAHASAN}

Pemilihan Model Regresi liniear berganda pada OLS

Model yang digunakan untuk melihat pengaruh Luas_lahan, Produksi karet dan Kurs rupiah terhadap dollar adalah sebagai berikut Untuk pemilihan model regresi liniear berganda(Ordinary Least Square). Hasil pengujiannya adalah sebagai berikut :

Tabel 1. Hasil regresi dengan metode OLS

\begin{tabular}{cccc}
\hline Variabel & Koefisien & Probabilitas & R-squared \\
\hline LUAS_LAHAN & 2.050024 & 0.030 & \\
PRODUKSI & 0.000368 & 0.001 & \\
KURS & 0.090445 & 0.001 & 0,654 \\
C & 605.7779 & 0.1559 &
\end{tabular}

Sumber: Data diolah dengan Eviews 6.0

Taraf signifikansi : $\alpha=5 \%$

Sumber : data diolah (eviews 6), 2015

Estimasi regresi berganda adalah sebagai $\mathrm{R}^{2}$ regresi utama. Apabila nilai $\mathrm{R}^{2}$ regresi parsial berikut:

(auxiliary regression) lebih besar dibandingkan Ekspor $=605.7779+2,050024$ Luas_lahan + nilai $\mathrm{R}^{2}$ regresi utama maka dapat disimpulkan 0,000368 Produksi karet $+0,090445$ Kurs rupiah terhadap dollar. bahwa dalam persamaan tersebut terjadi multikolinieritas.

Hasil uji multikolinearitas antara variabel

\section{Hasil uji Asumsi Klasik} independen sebagai berikut :

Berdasarkan perbandingan antara nilai $\mathrm{R}^{2}$ regresi parsial (auxiliary regression) dengan nilai

Tabel 2. Uji Multikolinearitas

\begin{tabular}{|c|c|c|c|}
\hline $\begin{array}{ll}\mathrm{R}_{2} & \text { model } \\
\text { utama } & \end{array}$ & \multicolumn{2}{|c|}{$\mathrm{R}_{2}$ model Penjelas } & Simpulan \\
\hline \multirow{3}{*}{0.938} & \multicolumn{2}{|c|}{$\mathrm{R}_{12}=0.444$ luaslahan(log(prod) $\log ($ kurs $\left.)\right)$} & Bebas Multikolenieritas \\
\hline & $\begin{array}{l}\mathrm{R}_{13} \quad=0.811 \\
(\log (\text { kurs }))\end{array}$ & Log(prod) (luaslahan & Bebas Multikolenieritas \\
\hline & $\begin{array}{l}\mathrm{R}_{14}=0.844, \\
(\log (\text { prod }))\end{array}$ & Log(kurs) (luaslahan & Bebas Multikolenieritas \\
\hline
\end{tabular}

Sumber: Data diolah dengan Eviews 6.0

Multikolinearitas 


\section{Hasil Koefisien Determinasi $\left(\mathrm{R}^{2}\right)$}

Tabel diatas menunjukkan besarnya pengaruh variabel independen luas lahan,produksi,dan kurs terhadap variabel dependen ekspor dapat dilihat nilai koefisien determinasi (R2) yaitu senbesar 0.938521 . Dengan demikian berarti bahwa 0.938521 mampu menjulaskan variabel dependen ekspor. Sedangkan sisanya sekitar $31 \%$ dijelaskan oleh variabel-variabel lain yang tidak termasuk dalam penelitian ini.

\section{Hasil Uji F-statistik}

Nilai uji F-statistik sebesar 137.3914 dan Prob. F-Statistik sebesar 0,000. Hal ini menunjukkan bahwa secara bersama-sama (uji serentak), variabel independen luas lahan, produksi dan kurs berpengaruh isgnifikan terhadap eksport karet Indonesia ke Malaysia.

\section{Hasil Uji t-statistik}

Prob $=0,0297<0,05$ jadi dapat disimpulkan luas lahan dari berpengaruh signifikan terhadap ekspor karet dari. Pada variable produksi diperoleh prob $=0,0005<$ 0,05 jadi dapat luas lahan berpengaruh signifikan terhadap ekspor karet. Pada variable kurs diperoleh prob $=0,0007<0,05$ jadi dapat disimpulkan perubahan kurs dari periode $t$ berpengaruh signifikan terhadap ekspor karet dari periode $t$.

\section{Interpretasi Hasil dan Pembahasan}

Pengaruh luas lahan Karet terhadap Ekspor Karet Indonesia ke Malaysia Tahun 1983-2013

Pengaruh lahan bergantung pada keadaan dan lingkungan lahan berada. Luas lahan pertanian merupakan sesuatu yang sangat penting dalam proses produksi. Dalam produksi karet misalnya pemilikan luas lahan yang sempit kurang maksimal di bandingkan denmgan luas lahan yang luas.

Proses produksi akan disesuaikan dengan luas lahan tersebut. Pada kondisi di lapangan bahwa pemanfaatan lahan yang akan memanfaatkan lahan kusus untuk ekspor karet tersebut.
Berdasarkan hasil olah data luas lahan berpengaruh positif terhadap produksi karet karena variabel luas lahan naik sebesar 2.050024 ton artinya ketika luas lahan naik 1 $\mathrm{Ha}$ akan meningkatkan produksi karet sebesar 2.050024 ton probabilitas 0,030 kurang dari 0,05 . Luas lahan perpengaruh signifikan dan parsial terhadap ekspor karet Indonesia ke Malaysia.

Luas lahan berpengaruh tidak sesuai dengan penelitian terdahulu yang dilakukan oleh Onike Siburian, (2012) dengan judul " Analisis faktor-faktor yang mempengaruhi ekspor karet alam Indonesia ke Singapura" Penelitian menyatakan bahwa dalam jangka pendek GDP singapura memiliki hubungan yang positif terhadap ekspor karet alam Indonesia ke Singapura dan jangka panjang GDP memiliki hubungan negatif. Harga karet alam Indonesia memiliki hubungan yang negatif terhadap ekspor karet alam Indonesia ke Singapura baik dalam jangka pendek maupun jangka panjang. Produksi karet alam Indonesia memiliki hubungan yang positif terhadap ekspor karet alam Indoneisia ke Singapura baik dalm jangka pendek maupun jangka panjang. Indonesia seharusnya mengingatkan produksi karet alam untuk meningkatkan eskpor karet alam yang akan meningkatkan pendapatan nasional Indonesia. Sebenarnya Malaysia merupakan Negara penghasil karet, namun kualitas karet Indonesia yang beriklim tropis jauh lebih bagus dibandingakn dengan kualitas karet di Malaysia, meskipun Malaysia telah mampu menghasilkan karet sendiri mereka tetap mengimpor dari Indonesia.

Perluasan luas areal lahan karet berakibat secara langsung pada meningkatnya jumlah produksi. negara produsen terdorong meningakatkan volume penjualan pada negara importer seiring dengan peningkatan jumlah produksi. Pembukaan lahan karet baru juga memudahkan importer untuk melihat dan memprediksi secara langsung hasil panen yang akan diperoleh. Banyaknya importer karet yang terjun langsung ke Indonesia setelah mengetahui banyaknya lahan baru yang dibuka secara otomotis meningkatkan transaksi penjualan 
karet dari Indonesia ke Malaysia, jadi ekspor karet dari Indonesia ke Malaysia pun meningkat.

\section{Pengaruh Produksi Karet terhadap Ekspor} Karet Indonesia ke Malaysia Tahun 1983-2013

Berdasarkan hasil olah data produksi berpengaruh positif terhadap ekspor karet karena variabel produksi sebesar 0.000368 artinya ketika produksi naik sebesar 1 ton akan meningkatkan produksi sebesar 0.000368 ton probabilitas 0,001 kurang dari 0,05. Produksi karet perbengaruh secara signifikan dan parsial terhadap ekspor karet Indonesia ke Malaysia.

Produksi karet berpengaruh terhadap ekspor karet Indonesia ke Malaysia sesuai dengan penelitian terdahulu yang dilakukan oleh Onike Siburian, (2012) dengan judul “ Analisis faktor-faktor yang mempengaruhi ekspor karet alam Indonesia ke Singapura" Penelitian menyatakan bahwa dalam jangka pendek GDP singapura memiliki hubungan yang positif terhadap ekspor karet alam Indonesia ke Singapura dan jangka panjang GDP memiliki hubungan negatif. Harga karet alam Indonesia memiliki hubungan yang negatif terhadap ekspor karet alam Indonesia ke Singapura baik dalam jangka pendek maupun jangka panjang. Produksi karet alam Indonesia memiliki hubungan yang positif terhadap ekspor karet alam Indoneisia ke Singapura baik dalm jangka pendek maupun jangka panjang. Indonesia seharusnya mengingatkan produksi karet alam untuk meningkatkan eskpor karet alam yang akan meningkatkan pendapatan nasional Indonesia.

Hasil penelitian menunjukan produksi karet Indonesia berpengaruh terhadap ekspor karet dari Indonesia ke Malaysia. Dari tahunketahunproduksi karet Indonesia mengalami kecendurungan meningakt, hal ini diikuti dengan semakin besarnya ekspor karet Indonsia ke Malaysia. Pada dasarnya karet dapat diperoleh menjadi bahan setengah jadi maupun barang jadi yang memiliki banyak nilai jual lebih tinggi, namun fakta dilapangan menunjukan sebagian besar ekspor karet Indonesia ke Malaysia berupakan bahan mentah. Langkah ini dipilih mengingat cara ini lebih praktis dan efisien.

\section{Pengaruh Kurs/Nilai Tukar Rupiah (Rp/US\$) terhadap Ekspor Karet Indonesia ke Malaysia Tahun 1983-2013}

Hasil estimasi kurs variabel nilai tukar rupiah terhadap dollar Amerika Serikat berpengaruh positif dan signifikan terhadap ekspor karet Indonesia ke Amerika Serikat. Nilai koefisienuntuk variabel nilai tukar rupiah terhadap dollar Amerika Serikat sebesar0,090445 artinya ketika kurrs meningkat sebesar 1 dollar rupiah maka akan meningkat sebesar 0,090445 rupiah dengan probabilitas 0.001 kurang dari 0,05. variabel nilai tukar rupiah terhadap dollar Amerika Serikat dengan variabel ekspor karet Indonesia ke Amerika Serikat.

Penelitian ini tidak sesuai dengan hasil penelitian Onike Siburian, (2012) dengan judul “ Analisis faktor-faktor yang mempengaruhi ekspor karet alam Indonesia ke Singapura" Penelitian menyatakan bahwa dalam jangka pendek GDP singapura memiliki hubungan yang positif terhadap ekspor karet alam Indonesia ke Singapura dan jangka panjang GDP memiliki hubungan negatif. Harga karet alam Indonesia memiliki hubungan yang negatif terhadap ekspor karet alam Indonesia ke Singapura baik dalam jangka pendek maupun jangka panjang. Produksi karet alam Indonesia memiliki hubungan yang positif terhadap ekspor karet alam Indoneisia ke Singapura baik dalm jangka pendek maupun jangka panjang. Indonesia seharusnya mengingatkan produksi karet alam untuk meningkatkan eskpor karet alam yang akan meningkatkan pendapatan nasional Indonesia. Penelitian menyatakan bahwa produksi berpengaruh terhadap ekspor karet alam Indonesia. Indonesia seharusnya mengingatkan produksi karet alam untuk meningkatkan eskpor karet alam yang akan meningkatkan pendapatan nasional Indonesia

Hasil penelitian menunjukan kurs dolar berpengaruh terhadap ekspor karet Indonesike Malaysia. Dari waktu ke waktu kurs rupiah terhadap dollar semakin naik, fenomena ini 
diikuti dengan kenaikan ekspor karet Indonesia ke Malaysia.

Peningkatan kurs mata uang negara pengimpor terhadap mata uang negara pengekspor dapat meningkatkan daya beli negara pengimpor yang mengakibatkan nilai ekspor negara pengekpor meningkat. Nilai tukar mata uang (kurs) memainkan peranan sentral dalam hubungan perdagangan internasional, karena kurs memungkinkan dapat membandingkan harga-harga barang dan jasa yang dihasilkan oleh suatu negara (Sukirno, 2000:109). Hal ini cukup rasional karena setiap unit dollar yang diperoleh dari kegiatan ekspor akan memperoleh rupiah yang lebih banyak. Penurunan nilai rupiah sama artinya dengan harga beli karet yang lebih murah, sementara dari pihak importer yang sebagian barangnya dijual kembali ke Negara tujuan ekspor akan mendatangkan keuntungan yang berlipat ganda.

\section{SIMPULAN}

Berdasarkan hasil analisis data yang telah dilakukan maka kesimpulan dalam penelitian ini adalah (1) Secara parsial luas lahan berpengaruh terhadap ekspor karet Indonesia ke Malaysia dengan nilai sebesar $2.050024 \mathrm{Ha}$ dan probabilitas 0.030 kurang dari 0,05, (2) Produksi karet berpengaruh positif terhadap ekspor karet Indonesia ke Malaysiadengan nilai koefisien sebesar 0.000368 ton dan probabilitas 0.001 kurang dari 0,05, (3) Kurs rupiah terhadap dollar berpengaruh positif terhadap ekspor karet Indonesia ke Malaysia dengan nilai koefisien sebesar 0.090445 rupiah dan probabilitas 0.001 kurang dari 0,05. Dari ketiga variabel tersebut pada luas lahan, produksi karet, dan kurs rupiah terhadap dollar menunjukkan pengaruh positif dan signifikan terhadap ekspor karet Indonesia ke Malaysia.

Saran yang dapat diberikan kepada pihak yang bersangkutan adalah (1) Sebaiknya pemerintah dan petani karet bekerjasama meminimalisir pengalihan lahan karet menjadi perumahan dan lahan-lahan lainya agar luas lahan yang digunakan untuk keboun karet tetap terjaga baik untuk saat ini maupun masa depan guna meningkatkan hasil produksi, (2) Untuk bisa menembus pasar dunia yang lebih luas sebaiknya petani karet Indonesia diberi subsidi bibit dan penyuluhan mengenai perawatan karet sehingga karet yang dihasilkan memiliki kualitas yang bagus, (3) Sebaiknya para eksportir mempelajaris trategi dagang internasional sehingga selalu dalam posisi tawar yang baik dalam kondisi apapun.

\section{DAFTAR PUSTAKA}

Ajija, Shochrul R, dkk. 2011. Cara Cerdas Menguasai Eviews. Jakarta: Salemba Empat

Ariefianto, Moch. Doddy. 2012. EkonometrikaEsensi dan Aplikasi Dengan Menggunakan Eviews. Jakarta: Erlangga.

Ayu Suresmiathi Dewi. 2013. Pengaruh Produksi,Kurs Dollar Amerika Serikat dan Luas Areal Lahan Terhadap Ekspor Karet Indonesia Tahun 1993-2013, Universitas Udayana.

Buediono. 2001. Ekonomi Internasional, Yogjakarta: BPFE.

Badan Pusat Statistik. 2014. www.bps.go.id (diakses tanggal 17 Desember 2013).

Direktorat Jenderal Perkebunan. 2012, Ekspor Karet Alam Indonesia. Tersedia di http:/Kedua". Tersedia diwww.deptan.go.id.

Fenske, James. 2013. Rubber will not keep in this country": Failed development in Benin, 18971921. Explorations in Economic History, 50(2, pp.316-333.

Food and Agliculture Organisation (FAO). 2012. Food and Agliculture Commodities Production. Tersedia di www.faostat.org .

Gujarati, Damodar. 2013. Dasar-Dasar Ekonometrika. Buku 1 Edisi 5. (Diterjemahkan Oleh Eugenia Mardanugrah, Dkk). Jakarta: Salemba Empat.

----- 2012. Dasar-dasar Ekonometrika. Buku 2 Edisi 5. (diterjemahkan oleh Eugeria Mardanugrah, dkk). Jkarta: Salemba empat.

Gabungan Perusahaan Karet Alam Indonesia (GAPKINDO).2012,Luas Perkebunan Karet Indonesia.Tersedia di www.gapkindo.org.

Kuncoro, Mudrajat, 1997, Ekonomi Pembangunan, Teori dan Aplikasi untuk Bisnis dan ekonomi, Yogyakarta : UPP AMP YKPN.

Lestari, Ayu. 2010 . Analisis faktor-faktor yang mempengaruhi ekspor karet alam Indonesia.

Mankiw, N. Gregory (2000). Pengantar Ekonomi Edisi kedua. Terjemahan oleh Drs Haris Munandar. Jakarta:Erlangga.

Nuhfil Hanani dan Fahriyah, 2012. Daya saing karet Indonesia di pasar internasional, Indonesia.

Siburian, O. (2012). Analisis Faktor-Faktor Yang Mempengaruhi Ekspor Karet Alam Indonesia Ke Singapura Tahun 1980-2010. Economics 
Development Analysis Journal, 1(2). doi:10.15294/edaj.v1i2.480

Prasetyo, P.Eko. 2009. Fundamental Makro Ekonomi. Yogyakarta: Beta Offset.

Putong, Iskandar. 2005. Teori Ekonomi Mikro. Jakarta: Mitra Wacana Media

Rosyidi, Suherman. 2006. Pengantar Teori Ekonomi. Surabaya: PT. Duta Jasa.

Ragimun. (2005)." Analisis daya saing karet dan produk dari karet Indonesia terhadap China". Jurnal Ekonomika dan Bisnis. Vol 2(1).

Salvatore, Dominick. 2014. Ekonomi Internasional. Edisi 9-Buku 1. Jakarta: Salemba Empat.

Shigematsu, Akira. 2013. Financial potential of rubber plantations considering rubberwood production: Wood and crop production nexus, Biomass and Bioenergy. Prosedia industry, 49, pp.131-142.

Sinaga, M. Bonar dan Elwamendri. 1999. "Perdagangan Karet Alam Antara Negara Produsen Utama dengan Amerika Serikat". Dalam jurnal. Tersedia di ejournal.unud.ac.id.

Sitepu, Muhammad Haikal, et al. 2016. Towards a Framework for Sustainable Development Planning in the Indonesian Natural Rubber Industry Supply Network. Procedia CIRP, 48, pp.164-169.

Sukirno, Sadono. 2005 Mikro Ekonomi: Teori Pengantar. Edisi ketiga. Jakarta: Raja Grafindo Persada.

Un Comtrade. diunduh dari www.Uncomtrade.com (diakses pada tanggal 16 Agustus 2015), pukul 11.00WIB. 